\title{
The (Anti-) Politics of Autonomy: Between Marxism and Anarchism ${ }^{i}$
}

\begin{abstract}
Christian Garland ${ }^{1}$
Marx famously said that the emancipation of the proletariat must be the work of the proletariat itself; almost ever since, there has been a persistent current of Marxism - that has, in common with anarchism and in antagonism toward its own dominant orthodox tradition, stressed the need for autonomy. This emphasis on 'autonomy' can be seen twofold: both in terms of the action of the exploited and oppressed themselves as an anti-political, self-valorising agency for achieving revolutionary social change, and as prefiguring new non-hierarchical social relations beyond the world of the present. This paper will aim to critically examine the concept of 'autonomy', specifically the similarities between unorthodox Marxisms and anarchism, rather than the all-too-frequently emphasised differences. The Greek origin of the word, comes of course, from 'auto' (self) and 'nomos' (law), meaning selfdetermination, and it is this original meaning that we can see in the context of the theories of anarchism and certain forms of Marxism, namely that any social subject must create and define the terms of its own collective existence. The Greek origins of the word 'anarchy' or 'anarchia' ('without ruler') bare striking similarity to the notion of an autonomous political practise which resists hierarchical forms, and seeks to become a 'self-creating' agency both acting and existing 'for itself' whilst seeking to push beyond the present form of society in subverting and undermining it. In the course of the paper, I will seek to identify some substantive claims of critical and libertarian currents of Marxism as they exist in relation to some of those made by anarchism, and the overlap that these two traditions share. [Article copies available for a fee from The Transformative Studies Institute. E-mail address:_ journal@transformativestudies.org Website: http://www.transformativestudies.org (C2010 by The Transformative Studies Institute. All rights reserved.]
\end{abstract}

KEYWORDS: Agency, Anarchism, Autonomism, Autonomy, Anti-Politics, Class Struggle, Marxism.

\footnotetext{
${ }^{1}$ Christian Garland, BA Philosophy and Politics (UEA), MA Social and Political Thought (Sussex), is currently an independent writer and researcher. He has research interests that include Critical Theory - Adorno, Benjamin, and the original Frankfurt School, and the intersection between autonomist Marxism and class-struggle anarchism, on which he has published papers and essays, and which will be the basis for a coauthored book with Benjamin Franks, in the next year or so. He intends to return to $\mathrm{PhD}$ studies in 2010 or 2011. Address correspondence to: Christian Garland; e-mail: christiangarland@hotmail.com.
} 